\title{
DEKADENSI MORAL SISWA DAN PENANGGULANGAN MELALUI PENDIDIKAN KARAKTER
}

\author{
Oleh: \\ Imam Taulabi \\ Institut Agama Islam Negeri (IAIN) Kediri \\ Bustomi Mustofa \\ bustomimustofa64@gmail.com \\ Institut Agama Islam Tribakti (IAIT) Kediri
}

\section{Abstrak}

Pendidikan karakter tumbuh menjadi salah satu tren dalam diskursus pendidikan nasional. Tulisan ini menjelaskan tentang dekandensi moral dan pendidikan karakter sebagai sebuah tawaran alternatif. Metode penelitian dalam tulisan ini menggunakan kajian literatur dengan memanfaatkan berbagai sumber yang relevan. Efektifitas penerapan pendidikan karakter dapat berlangsung secara optimal dengan melibatkan seluruh elemen secara sistemik dan berkelanjutan antara orang tua, sekolah, dan masyarakat. Penerapan pendidikan karakter di sekolah dapat dilakukan dengan memanfaatkan beberapa model dan metode. Model penerapannya meliputi model otonomi, model integrasi, model ekstrakurikuler, dan model kolaborasi. Selain itu, metode penerapan pendidikan karakter yang dilaksanakan di sekolah dapat dilakukan dengan empat cara, yaitu: belajar, keteladanan, penguatan, dan habituasi.

Kata Kunci: Dekadensi Moral, Pendidikan Karakter.

\section{Pendahuluan}

Indonesia memiliki berbagai bentuk keragaman dalam bahasa, suku, ras, budaya dan agama. Selain itu, Indonesia sebagai negara yang menjunjung tinggi nilai-nilai toleransi telah dipercaya menyelenggarakan even internasional sebagai tuan rumah United Nations Alliance of Civilizations (UNAOC) yang 
diadakan di Nusa Dua Bali pada bulan Agustus tahun 2014. Pilihan Indonesia sebagai tuan rumah dapat diartikan sebagai bentuk pencapaian internasional dan penghargaan bahwa Indonesia dapat menjadi panutan untuk bagaimana suatu negara selaras antara keragaman etnis, agama, ras dan budaya. ${ }^{1}$ Jika kita melihat pendapat dan fakta ini, tentu kita akan menganggap bahwa penduduk Indonesia memiliki pendidikan moral yang tinggi. Mengapa? karena toleransi harus berbanding lurus dengan moralitas. Suatu bangsa yang menjunjung tinggi toleransi, tentu saja memiliki moral yang sangat tinggi sebagai bagian dari produk pendidikan yang sedang berkembang di suatu bangsa. Bentuk toleransi yang ditegakkan yaitu toleransi agama dan toleransi sosial. ${ }^{2}$ Dengan begitu, penguatan bentuk toleransi akan berkontribusi pada terciptanya masyarakat multikultur. Karena senyatanya, perbedaan bukan suatu masalah dan dapat berlangsung dengan baik dan rukun. ${ }^{3}$

Tetapi ini tampaknya bertentangan dengan apa yang seharusnya terjadi. Seperti yang kita ketahui hari ini di liputan media massa atau hal-hal yang terjadi di sekitar kita, kita tahu bahwa saat ini di Indonesia ruang lingkup pendidikan, terutama di sekolah, merajalela dalam kasus-kasus perkelahian pelajar, bullying, kasus korupsi, penggunaan obat-obatan, seks bebas, pelecehan seksual, pelecehan guru, dan sebagainya. Hal ini tampaknya menodai nama baik orang Indonesia dan menjadi suatu ironi. Dari sekian banyak masalah yang terjadi, ini menunjukkan bahwa masyarakat Indonesia saat ini mungkin tengah mengalami krisis sosial.

${ }^{1}$ Iqbal Fadillah dalam http://jurnalintelijen.net/2017/06/09/indonesianegara-paling-menjunjung-tinggi-toleransi/, diakses tanggal 3 Maret 2018.

2 A. Jauhar Fuad, "Pembelajaran Toleransi: Upaya Guru Pendidikan Agama Islam Dalam Menangkal Paham Radikal Di Sekolah", Proceedings of Annual Conference for Muslim Scholars, no. series 2 (April 22, 2018): 566.

3 Jauhar Fuad, "Perguruan Tinggi Dan Pendidikan Multikultural," Jurnal Pemikiran Keislaman 22, no. 2 (2011), https://doi.org/10.33367/tribakti.v22i2.88. 
Masalah dalam ruang lingkup pendidikan di Indonesia, khususnya di ranah sekolah juga berkontribusi atas berbagai permasalahan nasional. Sebagai contoh, kita sering menemukan siswa sering berbohong pada hal-hal yang telah dilakukan, kita sering melihat berita di televisi dan media sosial tentang perkelahian antar siswa. Jika kita memperhatikan siswa di sekitar kita, tampaknya ada kurangnya rasa hormat terhadap anak-anak terhadap orang tua dan guru, pembicaraan komunikasi yang kasar dan bahkan ungkapan kata-kata kotor dan kasar seolah-olah mereka terbiasa, dan hal yang paling mengganggu adalah bahwa $68 \%$ siswa sekolah dasar menykasikan konten gambar pornografi. Menurut data dari Kementerian Komunikasi dan Teknologi Informasi, Indonesia sejauh ini menempati peringkat pertama dalam mengakses situssitus porno. Paradoksnya, di antara mereka yang mengakses situs porno adalah anak di bawah umur. ${ }^{4}$ Tidak hanya itu, siswa yang melakukan tindak kriminal juga seakan tak pernah berhenti seperti; melakukan pencurian, melakukan pelecehan seksual di bawah umur, penindasan atau tindakan kekerasan yang menyebabkan kematian.

Perilaku semacam ini merupakan indikasi bahwa telah terjadi kemerosotan moral dan etika di kalangan siswa sekolah di Indonesia. Banyak faktor yang menjadi penyebabnya, antara lain; kuatnya pengaruh kemajuan teknologi informasi yang sulit disaring, lemahnya kemampuan dalam menyaring informasi, asosiasi gratis, program televisi yang tidak mendidik sama sekali, pemilik media yang hanya memprioritaskan untung. Faktor lain adalah buruknya pengawasan orang tua dan lembaga pendidikan karena pada dasarnya membutuhkan anak-anak untuk berkuasa, memahami dan memperlakukan cinta dalam hal memahami dan memahami tindakan yang mereka ambil.

4 Ramadhian Fadillah dalam https://www.merdeka.com, diakses tanggal 3 Maret 2018. 
Hal ini semakin menguatkan bahwa pada dasarnya pendidikan karakter masih menjadi salah satu solusi yang dapat digunakan oleh pendidik atau lembaga pendidikan, orang tua dan masyarakat, terutama dengan menggunakan pendekatan keteladanan. Ini juga salah satu alasan mengapa pendidikan karakter masih relevan untuk terus-menerus didengungkan dan dipraktekkan dalam berbagai lingkup, terutama dalam lingkup sekolah. Dalam hal ini, Lickona seperti dikutip Samani dan Hariyanto menjelaskan bahwa pendidikan karakter adalah upaya yang dirancang dengan sengaja untuk meningkatkan karakter siswa. ${ }^{5}$ Salah satu tujuan pendidikan karakter itu sendiri adalah untuk mengembangkan kebiasaan dan perilaku siswa yang terpuji dan sejalan dengan nilai-nilai universal, tradisi, budaya, dan agama. ${ }^{6}$

\section{Dekadensi Moral}

Hurlock menjelaskan bahwa dekadensi moral adalah prosedur adat di mana perilaku seseorang dikendalikan oleh konsep moral tertentu dan telah menjadi kebiasaan bagi mereka sebagaimana harapan suatu komunitas atau kelompok sosial tertentu. ${ }^{7}$ Jadi yang dimaksud dengan dekadensi moral adalah kondisi di mana individu dalam suatu kelompok masyarakat tidak mematuhi aturan atau norma yang telah diterapkan dan berlaku yang terwujud dalam perilaku atau interaksi dengan orang lain dan lingkungannya.

Berkaitan dengan itu, kondisi kesadaran masyarakat akan masalah moral juga perlu ditingkatkan untuk membantu perkembangan moral siswa dalam kehidupan kesehariannya.

5 Mukhlas Samani dan Hariyanto, Pendidikan Karakter (Bandung: Remaja Rosdakarya, 2013), h. 44.

6 Kemendikdas, Model Pembinaan Pendidikan Karakter di Lingkungan Sekolah (Jakarta: 2010), h. 7.

7 Elizabeth B. Hurlock, Perkembangan Anak (Jakarta: Erlangga, 1993), h. 74.

Volume 30 Nomor 1 Januari-Juni 2019 
Karena masyarakat memiliki kontribusi penting dalam mengarahkan moral individu. Untuk kepentingan itu, kesadaran masyarakat dapat dimulai dengan memahami gejala penyimpangan moral. Dalam hal ini, Lickona menginformasikan beberapa gejala penurunan moral, antara lain; kekerasan dan tindakan anarki, pencurian, tindakan kecurangan, abaikan aturan yang berlaku, pertarungan antar siswa, ketidakteraturan, penggunaan bahasa yang buruk, kematangan seksual terlalu dini dan penyimpangan, sikap penghancuran diri, penyalahgunaan narkoba. ${ }^{8}$

Indikator-indikator tersebut harus dipahami semua pihak sebagai instrument dalam membaca problem moral siswa. Karena pembentukan karakter siswa sebagai seorang anak bukan hanya tugas guru semata. Di samping itu, tanpa kerja sama yang kuat antar orang tua, guru, dan masyarakat pembentukan dan perbaikan karakter akan sulit terealisasi secara maksimal. Gejala dekadensi moral seperti yang disebutkan oleh Lickona sebenarnya juga terjadi di Indonesia. Media massa telah banyak merekam dan menginformasikan problem moral, misalnya, kasus pemukulan siswa terhadap guru menyebabkan kematian oleh siswa SMAN 1 Torjun di Sampang, Madura. Hanya karena dia tidak mau mematuhi instruksi yang diberikan oleh gurunya, seseorang memukul kepala gurunya tepat di pelipis kanannya hingga jatuh. ${ }^{9}$

Contoh lain adalah kasus pencurian helm di SMN 1 Gunung Putri Bogor. Pada akhirnya terungkap bahwa pelaku pencurian adalah siswa kelas II SMP 1 Gunung Putri yang ditangkap melalui CCTV. Penangkapan ini berasal dari banyak keluhan dari siswa SMP 1 yang dilaporkan sering kehilangan

8 Thomas Lickona, Mendidik Untuk Membentuk Karakter (Jakarta: Remaja Rosdakarya, 2013), h. 20.

${ }^{9}$ https://regional.kompas.com, diakses tanggal 3 Maret 2018. 
Dekadensi Moral... Oleh: Imam Taulabi \& Bustomi Mustofa

helm. ${ }^{10}$ Tidak kurang menyedihkan adalah video bullying siswa sekolah menengah. Kejadian ini dialami oleh seorang siswi di SMP Pangkalpinang 3 Bangka. Video yang berdurasi 2 hingga 3 menit itu berisi tayangan seorang siswi yang dipaksa bersujud dan mencium kaki teman sekolahnya setelah perbedaan cara mereka ditendang dan dipukuli kemudian direkam. ${ }^{11}$

Kasus berikutnya adalah tentang pelecehan seksual. Siswa kelas satu yang menjadi korban penganiayaan oleh 6 teman sekelas di Anjir, Muara Barito Kuala, Banjarmasin. Pelecehan ini terjadi sekitar awal September 2017. Setelah menerima laporan dari tetangga, ayah korban mengklarifikasi para pelaku penganiayaan dan menanyainya secara langsung. Dengan mudah anak-anak mengakui tindakan mereka. Insiden itu akhirnya dilaporkan ke polisi setempat dan korban dibawa ke Puskesmas dan dari hasil post mortem di Puskesmas juga menyatakan bahwa korban mengalami luka positif pada alat kelaminnya. ${ }^{12}$

Kasus lain dialami oleh Edi Gilang Febriyanto, siswa SMK Bina Insan Kamil Jatikramat, Jakarta. Korban perkelahian yang mati karena terkena semburan arit di lehernya. Korban tidak tahu tentang tawuran antar sekolah. Setelah sekolah ia hanya mengundang para seniornya (para senior) bersama untuk pergi ke Jatibening. Setibanya di sana, mereka bertemu dengan satu kelompok dari Sekolah Kejuruan Jatibening Abdi Karya dan terjadi perkelahian yang menyebabkan korban jiwa. ${ }^{13}$

Dengan mempertimbangkan munculnya berbagai problem mulai dari kekerasan, pencurian, penindasan, pelecehan seksual, bahkan perkelahian antar siswa dan mengakibatkan kematian. Maka asumsi mengenai dekadensi moral dalam pendidikan tidak bisa diabaikan. Sehingga pendidik dan sekolah tidak mempunyai

${ }^{10}$ Yusuf Asyari dalam jawapos.com, diakses tanggal 3 Maret 2018.

${ }^{11}$ Bangka.tribunnews.com diakses tanggal 3 Maret 2018.

12 Banjarmasin.tribunnews.com, diakses tanggal 3 Maret 2018.

13 Mey Amelia dalam http://m.detik.com, diakses tanggal 3 Maret 2018.

Volume 30 Nomor 1 Januari-Juni 2019 
alasan untuk tidak mengajarkan pendidikan karakter secara terpusat, sistematis dan terintegrasi. Pembasisan pendidikan karakter dapat dilakukan dalam berbagai bentuk dan tidak hanya terpraktekkan dalam kurikulum pembelajaran. Melainkan dapat ditekankan pula dalam iklim atau budaya sekolah. Dengan demikian diharapkan dapat mengurangi dekadensi moral yang terjadi saat ini.

\section{Konsep dan Urgensi Karakter dalam Pendidikan}

Kata karakter berasal dari kata Yunani charassein, yang berarti mengukir (melukis, menggambar), seperti orang yang melukis kertas, memahat batu atau logam. Karakter kemudian diartikan sebagai tanda atau karakteristik khusus. Oleh karena itu, ada pandangan bahwa karakter adalah pola perilaku individu, keadaan moral seseorang. Setelah melewati tahap anak, seseorang memiliki karakter. Karakter yang terbentuk terkait dengan perilaku di sekelilingnya. ${ }^{14}$ Karakter adalah kualitas, mental atau kekuatan moral, moral atau karakter individu yang merupakan kepribadian khusus yang menjadi dorongan dan mobilisasi, dan membedakan individu dari individu lain. ${ }^{15}$

Karakter yang baik berhubungan dengan mengetahui yang baik (mencintai yang baik), mencintai yang baik (mencintai yang baik), dan berbuat baik (bertindak baik). Ketiganya sangat terkait erat. Seseorang yang terlahir dalam ketidaktahuan, impuls primitif yang ada dalam dirinya cenderung mampu menguasai akal sehatnya. Oleh karena itu, kebutuhan akan pola asuhan dan pendidikan untuk bimbingan penalaran serta ajaran

${ }^{14}$ Kevin Ryan dan Karen E. Bohlin, Building Character in Schools: Practical Way to Bring Moral Instruction For Life, (San Francisco: JOSSEY-BASS Wiley Imprint, 1999), h. 5.

15 Endhang Suhilmiati, Revitalisasi Pendidikan Karakter Melalui kegiatan Training of Trainer, (Kediri: Intelektual Jurnal Pendidikan Islam Tribakti, Vol. 7, No. 2, Agustus 2017), h. 177. 
agama akan dapat mengarahkan kecenderungan, perasaan, dan semangat seseorang untuk berada dalam keharmonisan.

Mengetahui yang baik berarti mampu memahami dan mampu membedakan mana yang baik dan mana yang buruk. Mengetahui yang baik berarti mengembangkan kemampuan untuk menyimpulkan suatu situasi, dan dengan sengaja memilih dan melakukan sesuatu yang baik untuk dilakukan. Aristoteles menyebut hal ini sebagai kebijaksanaan praktis. Seseorang yang memiliki kebijakan praktis berarti mengetahui apa yang dibutuhkan dan situasi yang diinginkan, sehingga karakter yang baik dikaitkan dengan perilaku yang benar dalam kaitannya dengan orang lain dan diri mereka sendiri. Di sisi lain, Michael Novak berpendapat bahwa karakter adalah campuran atau kombinasi dari semua kebaikan yang berasal dari tradisi agama, cerita, dan pendapat orang-orang bijak, yang mencapai kita melalui sejarah. Seseorang dengan karakter terpuji dapat dibedakan dari yang lain. ${ }^{16}$

Penguatan karakter dalam pendidikan menjadi kebutuhan mendasar bagi masyarakat. ${ }^{17}$ Pendidikan karakter dapat diartikan sebagai pendidikan nilai, pendidikan karakter, pendidikan karakter, pendidikan moral yang bertujuan mengembangkan kemampuan siswa untuk menentukan sesuatu yang baik dan sesuatu yang buruk, menjaga apa yang dianggap baik, dan menerapkan kebaikan dalam kehidupan mereka seharihari. Samani dan Hariyanto berpendapat bahwa pendidikan karakter adalah proses pemberian bimbingan kepada siswa untuk menjadi karakter manusia sepenuhnya dalam dimensi hati,

16 Thomas Lickona, Educating For Character: How Our School Can Teach Respect And Responsibility (New York: Bantam Book, 1991), h. 50.

17 Jauhar Fuad, "Pendidikan Karakter Dalam Pesantren Tasawuf," Jurnal Pemikiran Keislaman 23, no. 1, February, 2013, http://ejournal.iaitribakti.ac.id/index.php/tribakti/article/view/13

Volume 30 Nomor 1 Januari-Juni 2019 
pikiran, tubuh, dan perasaan serta niat. ${ }^{18}$ Suyanto merumuskan bahwa pendidikan karakter adalah pendidikan karakter plus, yang melibatkan aspek pengetahuan (kognitif), perasaan (perasaan), dan tindakan (tindakan). ${ }^{19}$ Kedua teori ini sejalan dengan pemikiran Lickona yang berpendapat bahwa dalam karakter yang baik harus ada tiga komponen, yaitu pengetahuan moral, perasaan moral, dan tindakan moral. Melalui ketiga komponen pendidikan karakter ini akan berjalan secara sistematis dan berkesinambungan sehingga siswa dapat menilai suatu tindakan melalui pengetahuan mereka, dapat merasakan suatu tindakan melalui perasaan moral mereka dan dapat memutuskan tindakan tersebut melalui tindakan moral yang dimiliki siswa. ${ }^{20}$

Tanpa ketiga komponen ini, pendidikan karakter tidak akan berjalan efektif. Dalam hal ini Sudarminta juga memformulasikan pentingnya pendidikan karakter di lingkungan sekolah, antara lain; 1). Sekolah adalah tempat dalam proses pembiasaan diri, mengetahui dan mematuhi aturan umum dan proses pembentukan identitas diri, 2) sekolah adalah tempat kedua sosialisasi setelah keluarga, dalam hal ini siswa diharapkan untuk menerima moral pendidikan yang tidak ada di keluarga, 3). Pendidikan di sekolah adalah proses membudayakan bagi siswa yang berisi pendidikan moral yang pada akhirnya akan membentuk karakter anak-anak bangsa.

Mengapa membutuhkan pendidikan karakter? Pendidikan sebenarnya memiliki dua tujuan, yaitu untuk membantu manusia menjadi pintar dan membantu manusia menjadi orang baik. Membuat orang pintar dan cerdas, adalah hal yang mudah

18 Mukhlas dan Harianto Samani, Pendidikan Karakter (Bandung: Remaja Rosdakarya, 2013), h. 45.

19 Kemendiknas, Model Pembinaan Pendidikan Karakter (Jakarta: 2010), h. 37.

20 Thomas Lickona, Mendidik Untuk Membentuk Karakter (Jakarta: Remaja Rosdakarya, 2013), h. 85. 
dilakukan, tetapi membuat orang menjadi orang yang baik dan bijaksana akan menjadi lebih sulit dan bahkan sangat sulit. Menjadi hal yang wajar untuk mengatakan bahwa masalah moral adalah masalah yang sangat penting. Kualitas moral dalam kehidupan manusia Indonesia saat ini, terutama di kalangan siswa, menuntut pembentukan pendidikan karakter. Sekolah dituntut untuk memainkan peran dan tanggung jawab mereka untuk menanamkan dan mengembangkan nilai-nilai yang baik dan membantu siswa membentuk dan membangun karakter mereka dengan nilai-nilai yang baik.

Pendidikan karakter diarahkan untuk memberikan nilainilai norma tertentu seperti; rasa hormat, tanggung jawab, kejujuran, kepedulian, dan keadilan, dan berusaha membantu siswa memahami, memperhatikan, dan melakukan nilai-nilai itu dalam kehidupan mereka sendiri. Lebih lanjut, Lickona mengungkapkan beberapa alasan mengapa pendidikan karakter menjadi kebutuhan bersama, antara lain untuk memastikan siswa memiliki kepribadian yang baik dalam hidup mereka, untuk meningkatkan prestasi akademik, membantu siswa membentuk karakter yang kuat untuk diri mereka sendiri, siapkan siswa untuk mentolerir kehidupan di komunitas yang beragam, mengatasi akar masalah yang terkait dengan masalah moral-sosial, siapkan siswa bagaimana berperilaku di tempat kerja nanti, pembelajaran nilai-nilai budaya yang merupakan bagian dari proses peradaban. ${ }^{21}$

\section{Deskripsi Nilai Pendidikan Karakter}

Nilai-nilai yang dikembangkan dalam pendidikan budaya dan karakter masyarakat Indonesia diidentifikasi dari empat sumber, termasuk: (1) Agama, (2) Pancasila, (3) Budaya, dan (4) Tujuan Pendidikan. Masyarakat Indonesia adalah masyarakat yang religius, oleh karena itu kehidupan individu, komunitas

${ }^{21}$ Endhang Suhilmiati, Revitalisasi Pendidikan Karakter, h.178.

Volume 30 Nomor 1 Januari-Juni 2019 
dan bangsa selalu didasari oleh ajaran agama. Negara Kesatuan Republik Indonesia ditegakkan pada prinsip kebangsaan dan kenegaraan yang disebut Pancasila, oleh karena itu Pancasila harus menjadi sumber nilai dalam kehidupan. Posisi budaya sebagai sumber nilai juga memainkan peran penting, serta tujuan pendidikan nasional yang telah merumuskan standar kualitas yang harus dimiliki oleh warga negara Indonesia. ${ }^{22}$

Nilai-nilai yang ditanamkan dan dikembangkan di sekolah-sekolah di Indonesia dan deskripsi mereka adalah sebagai berikut:

1. Agama. Sikap dan perilaku yang patuh menjalankan ajaran agama yang mereka patuhi, serta toleran terhadap pelaksanaan ibadah agama-agama lain, dan hidup harmonis di antara komunitas-komunitas agama.

2. Jujur. Perilaku yang berusaha menjadikan dirinya orang yang selalu bisa dipercaya dalam kata-kata, tindakan, dan tindakan.

3. Toleransi. Sikap menghormati perbedaan dalam agama, etnis, etnis, pendapat, sikap, dan tindakan orang lain berbeda dari dirinya.

4. Disiplin. Perilaku terstruktur sesuai dengan berbagai peraturan dan ketentuan.

5. Kerja Keras. Upaya serius untuk mengatasi berbagai kendala dalam pembelajaran dan tugas, dan menyelesaikannya sebanyak mungkin.

6. Kreatif. Pikirkan dan lakukan sesuatu yang menghasilkan sesuatu yang baru dari sesuatu yang telah dimiliki.

7. Mandiri. Sikap tidak mudah tergantung pada orang lain.

8. Demokratis. Bagaimana cara berpikir, bertindak, dan bertindak untuk menilai hak dan kewajiban yang sama dengan orang lain.

${ }^{22}$ Balitbang Puskur, Pengembangan Pendidikan Budaya dan Karakter Bangsa: Pedoman Sekolah (Jakarta: Kemdikdas, 2010), h. 8-10. 
9. Keingintahuan. Berusaha untuk mengetahui lebih dalam tentang sesuatu yang dipelajari, didengar, dan dilihat.

10. Nasionalisme. Cara berpikir menempatkan kepentingan bangsa dan negara di atas kepentingan diri mereka sendiri dan kelompok mereka.

11. Cintai negeri ini. Cara berpikir menunjukkan kesetiaan, kepedulian, dan penghargaan yang tinggi untuk lingkungan bahasa, fisik, sosial, budaya, ekonomi dan politik bangsa.

12. Menghargai Prestasi. Sikap yang mendorong diri untuk menghasilkan sesuatu yang berguna bagi komunitas, mengakui, dan menghormati keberhasilan orang lain.

13. Ramah / Komunikatif. Tindakan yang menunjukkan kesenangan dalam bersosialisasi, berbicara, dan bekerja dengan orang lain.

14. Cinta Damai. Sikap, kata-kata, dan tindakan yang menyebabkan orang lain merasa aman dan bahagia atas kehadiran mereka.

15. Suka Membaca. Kebiasaan menyediakan waktu untuk membaca berbagai bacaan yang bermanfaat.

16. Peduli Lingkungan. Sikap dan tindakan untuk mencegah kerusakan lingkungan alam sekitarnya, dan mengembangkan upaya untuk memperbaiki kerusakan alami.

17. Perawatan Sosial. Sikap dan tindakan ingin memberikan bantuan kepada orang lain dan komunitas yang membutuhkan.

18. Tanggung jawab. Sikap dan perilaku seseorang untuk melaksanakan tugas dan kewajibannya, yang harus dia lakukan, terhadap diri sendiri, masyarakat, lingkungan, negara dan Tuhan Yang Maha Kuasa. ${ }^{23}$

${ }^{23}$ Ajat Sudrajat, "Mengapa Pendidikan Karakter", Jurnal Pendidikan Karakter, Oktober 2011, h.56. 


\section{Metode dan Aplikasi Model Pendidikan Karakter}

Penerapan metode dan model pendidikan karakter akan berfungsi efektif dengan mempertimbangn prinsip-prinsipnya. Dalam kaitan ini, Lickona telah menginformasikan 11 prinsip pendidikan karakter yang diperoleh dari hasil pengembangannya. Prinsip ini dapat dijadikan acuan implementasi pendidikan karakter dalam konteks pendidikan di Indonesia. Berikut ini prinsip-prinsip pendidikan karakter menurut Lickona seperti dikutip oleh Asep Jihad, dkk: ${ }^{24}$

1. Mengembangkan nilai-nilai etika dasar dan mendukung nilai-nilai kinerja sebagai struktur atau fondasi awal.

2. Pilih "kepribadian" secara keseluruhan yang mencakup pikiran, perasaan, dan perilaku.

3. Gunakan pendekatan yang komprehensif, proaktif, dan disengaja.

4. Menciptakan komunitas peduli di lingkungan sekolah.

5. Beri siswa kesempatan untuk mengambil tindakan moral.

6. Buat kurikulum akademik yang sulit dan bermanfaat yang menghormati semua siswa, mengembangkan pribadi dan membantu siswa berhasil.

7. Berikan motivasi kepada siswa.

8. Libatkan staf sekolah sebagai komunitas pendidikan dan moral.

9. Mengembangkan rasa solidaritas dan kepemimpinan moral.

10. Melibatkan keluarga sebagai mitra dan anggota masyarakat.

11. Penilaian kepribadian sekolah, fungsi staf sekolah sebagai guru kerajinan tangan, penilaian serat tentang sejauh mana siswa menunjukkan karakter yang baik.

Prinsip di atas merupakan landasan dan langkah awal dalam menerapkan pendidikan karakter di sekolah. Dalam proses pembelajaran yang berlangsung di dalam kelas, prinsip-

${ }^{24}$ Asep Jihad dkk., Pendidikan Karakter Teori dan Aplikasi (Jakarta: Dirjenmandikdasmen, 2010), h. 69. 
prinsip tersebut juga akan memudahkan guru dalam mengarahkan peserta didik menjadi insan berkarakter. Pertama adalah pengetahuan moral. Pada tahap ini siswa diarahkan agar dapat membedakan kebaikan dari keburukan, perilaku baik atau perilaku buruk, dan sebagainya terkait moral terutama yang hidup dan berlaku di lingkungan masyarakat tempat mereka tinggal. Kedua adalah kecintaan moral. Pada tahap ini siswa diarahkan untuk menumbuhkan rasa cinta dan kebutuhan akan nilai-nilai moral yang luhur. Ketiga adalah perilaku moral. Tahap ini merupakan tahap pelaksanaan bagi siswa dalam mempraktekkan nilai-nilai moral pada kehidupan keseharian mereka.

Dalam kaitan itu, terdapat empat model implementasi pendidikan karakter di sekolah. Pertama, model otonomi. Model ini menempatkan pendidikan karakter sebagai subjek yang terpisah. Kedua, model integrasi. Model ini menyatukan nilainilai dan karakter yang akan terbentuk di semua mata pelajaran. Ketiga, model ekstrakurikuler. Model ini dilaksanakan melalui kegiatan tambahan yang berorientasi pada pembentukan karakter untuk siswa. Keempat, model kolaborasi. Model ini menggabungkan ketiga model sebelumnya pada semua kegiatan sekolah. ${ }^{25}$

Keempat model tersebut tampaknya telah disiapkan berdasarkan tahap penerapannya di sekolah. Model otonomi akan sangat baik dilaksanakan bagi sekolah yang baru memulai penerapan pendidikan karakter. Pada prakteknya, model ini dapat berupa pengambilan kebijakan komite sekolah untuk menerapkan pendidikan karakter. Kemudian kebijakan tersebut disosialisasikan di lingkungan sekolah secara bertahap mulai dari dewan guru, staff, dan siswa dengan cara beragam. Sedangkan pada model integrasi pelaksanaan penguatan

25 Kemendiknas, Model Pembinaan Pendidikan Karakter (Jakarta: Kemedikbud2010), h. 71.

Volume 30 Nomor 1 Januari-Juni 2019 


\section{Dekadensi Moral... Oleh: Imam Taulabi \& Bustomi Mustofa}

pendidikan karakter telah merambat pada proses pembelajaran di kelas dengan memanfaatkan sebagian atau seluruh mata pelajaran sebagai media menyosialisasikan nilai-nilai karakter pada peserta didik baik secara normatif yang mengacu pada ajaran agama, moral masyarakat maupun dengan pendekatan saintifik.

Adapun model ekstrakurikuler tercermin pada program sekolah seperti ekstrakurikuler baca tulis al-Quran, olah raga, kesenian, dan sebagainya. Seluruh program tidak hanya menjalankan fungsinya sebagai kegiatan tambahan untuk meningkatkan pengetahun dan keterampilan siswa di luar jam belajar. Akan tetapi beragam kegiatan tambahan itu juga dapat dijadikan media untuk menanamkan nilai-nilai karakter pada diri peserta didik. Tahap akhir dari ketiga model itu kemudian menjadi model ideal implementasi pendidikan karakter yang berlangsung dari proses perencanaan hingga terbentuknya iklim sekolah yang mendorong penguatan karakter bagi peserta didik secara menyeluruh. Setidaknya ini adalah maksud dari model implementasi pendidikan karakter kolaboratif.

Selain 4 model di atas, keberadaan strategi dalam implementasinya akan lebih membantu dalam mewujudkan tujuan pendidikan karakter. Strategi untuk menerapkan pendidikan karakter yang diterapkan di sekolah dapat dilakukan dengan empat cara, yaitu: (1) mengajar (2) teladan (pemodelan), (3) penguatan, dan (4) pembiasaan. Pendidikan karakter yang efektif ditentukan oleh adanya empat strategi yang dilakukan secara bersamaan dan terus menerus. Pendekatan strategis untuk implementasi ini juga melibatkan tiga komponen yang saling terkait, yaitu: (1) sekolah (kampus), (2) keluarga, dan (3) masyarakat. ${ }^{26}$

Ketika komponen sekolah mengimplementasikan dan menerapkan nilai-nilai yang ditentukan, setiap guru harus selalu

\footnotetext{
${ }^{26}$ Ajat Sudrajat, Mengapa Pendidikan Karakter, h. 55.
} 
menyampaikannya melalui pembelajaran langsung (sebagai pelajaran khusus) atau dengan memasukkannya ke dalam setiap topik. Nilai-nilai prioritas harus dirancang secara teratur dan terus menerus oleh semua anggota sekolah (universitas), petugas keamanan, pemantau parkir, petugas kebersihan, staf administrasi, guru, dan pemimpin sekolah. Nilai-nilai ini harus diperkuat melalui pengelolaan lingkungan dan kegiatan di lingkungan sekolah melalui penempatan spanduk atau tandatanda yang memberikan dukungan dan mengarah pada pembentukan suasana sekolah yang baik.

Penguatan juga harus melibatkan komponen keluarga dan masyarakat. Komponen keluarga termasuk pengembangan dan pembentukan karakter di rumah untuk lebih peduli tentang perilaku anak-anak mereka. Sedangkan komponen dalam masyarakat adalah sebagai alat kontrol sebagai wahana latihan bagi perilaku siswa dalam mengembangkan dan membentuk karakter mereka. Sekolah (kampus) dapat berkomunikasi dan berinteraksi dengan keluarga dan masyarakat secara teratur. Kebiasaan dapat dilakukan di sekolah dengan berbagai cara dan melibatkan banyak hal seperti etika pakaian, etika sosial, disiplin waktu, perlakuan siswa terhadap guru, karyawan, dan pemimpin, dan sebaliknya. Habituasi yang dilakukan oleh pemimpin, guru, karyawan, dan siswa, dalam disiplin sebuah lembaga pendidikan merupakan langkah yang sangat strategis dalam membentuk karakter bersama. Dengan demikian pendidikan karakter akan terwujud jika dari berbagai pihak turut serta mewujudkannya. Masa depan akan mampu mengurangi krisis moral yang sedang terjadi di negeri ini.

\section{Penutup}

Dekadensi moral adalah suatu kondisi di mana individu dan kelompok masyarakat tidak mematuhi standar moral yang diterapkan dalam masyarakat berkaitan dengan aktivitas 
manusia yang dianggap baik atau buruk, benar atau salah, benar atau salah dalam kaitannya dengan pelaksanaan interaksi dengan orang lain dan lingkungannya. Pribadi adalah kualitas, kekuatan mental atau moral, kepribadian moral atau individu yang merupakan kepribadian tertentu yang menjadi dorongan dan mobilisasi, dan membedakan individu dari individu lain.

Sikap yang baik terkait dengan pengetahuan tentang kebaikan dan cinta dan untuk melakukan pekerjaan dengan baik. Pendidikan pribadi adalah proses memberikan bimbingan kepada siswa untuk menjadi simbol manusia penuh dalam dimensi hati, pikiran, tubuh, perasaan dan niat. Membuat orang cerdas dan cerdas itu mudah, tetapi membuat orang baik dan bijaksana dan menjadikan mereka kepribadian akan lebih sulit dan bahkan lebih sulit.

Dalam implementasi pendidikan karakter di sekolah, ada empat model: model kemandirian, model integrasi, model ekstrakurikuler, model kolaboratif. Selain itu, strategi implementasi untuk pendidikan karakter di sekolah dapat diimplementasikan dengan empat cara: pembelajaran, idealisme, promosi, dan keakraban. Pendidikan karakter akan tercapai jika dari pihak yang berbeda, baik di rumah maupun di rumah, untuk berpartisipasi dalam mencapainya. Sehingga menjadi langkah efektif untuk mengatasi pembusukan moral yang terjadi di negara ini. 
Amelia, Mey. dalam http://m.detik.com, diakses tanggal 3 Maret 2018.

Asyari, Yusuf. dalam jawapos.com, diakses tanggal 3 Maret 2018.

Balitbang Puskur. Pengembangan Pendidikan Budaya dan Karakter Bangsa: Pedoman Sekolah. Jakarta: Kemdikdas, 2010.

Bangka.tribunnews.com diakses tanggal 3 Maret 2018.

Banjarmasin.tribunnews.com, diakses tanggal 3 Maret 2018.

Fadillah, Iqbal. dalam http://jurnalintelijen.net/2017/06/09/indonesia-negarapaling-menjunjung-tinggi-toleransi/, diakses tanggal 3 Maret 2018.

Fadillah, Ramadhian. dalam https://www.merdeka.com, diakses tanggal 3 Maret 2018.

Fuad, A. Jauhar. Pembelajaran Toleransi: Upaya Guru Pendidikan Agama Islam Dalam Menangkal Paham Radikal Di Sekolah, Proceedings of Annual Conference for Muslim Scholars, no. series 2, April 2018.

Fuad, A. Jauhar. Perguruan Tinggi Dan Pendidikan Multikultural, Jurnal Pemikiran Keislaman 22, no. 2, 2011, https://doi.org/10.33367/tribakti.v22i2.88.

Fuad, A. Jauhar. Pendidikan Karakter dalam Pesantren Tasawuf. Jurnal Pemikiran Keislaman. No. 1, February 2013, http://ejournal.iaitribakti.ac.id/index.php/tribakti/article/view/13

https://regional.kompas.com, diakses tanggal 3 Maret 2018.

Hurlock, Elizabeth B. Perkembangan Anak. Jakarta: Erlangga, 1993. 
Jihad, Asep. Pendidikan Karakter Teori dan Aplikasi. Jakarta: Dirjenmandikdasmen, 2010.

Kemendikdas. Model Pembinaan Pendidikan Karakter di Lingkungan Sekolah. Jakarta: 2010.

Lickona, Thomas. Mendidik Untuk Membentuk Karakter. Jakarta: Remaja Rosdakarya, 2013.

Lickona, Thomas. Educating For Character: How Our School Can Teach Respect And Responsibility. New York: Bantam Book, 1991.

Ryan, Kevin and Karen E. Bohlin. Building Character in Schools: Practical Way to Bring Moral Instruction For Life. San Francisco: JOSSEY-BASS Wiley Imprint, 1999.

Samani, Mukhlas dan Hariyanto. Pendidikan Karakter. Bandung: Remaja Rosdakarya, 2013.

Sudrajat, Ajat. Mengapa Pendidikan Karakter, Jurnal Pendidikan Karakter, Oktober 2011.

Suhilmiati, Endhang. Revitalisasi Pendidikan Karakter Melalui kegiatan Training of Trainer. Intelektua: Jurnal Pendidikan Islam Tribakti, Vol. 7, No. 2, Agustus 2017. 